\title{
Spatial variability in the population structure of the shore crab Carcinus maenas (Crustacea: Brachyura) in a shallow-water, weakly tidal fjord
}

\author{
P. Abelló ${ }^{1, *}$, A. Aagaard ${ }^{2}$, C. G. Warman ${ }^{3}$, M. H. Depledge ${ }^{3}$ \\ ${ }^{1}$ Institut de Ciències del Mar (CSIC), Passeig Joan de Borbó s/n, E-08039 Barcelona, Spain \\ ${ }^{2}$ Danish Environmental Protection Agency, Stangade 29, DK-1401 Copenhagen K, Denmark \\ ${ }^{3}$ Plymouth Environmental Research Centre, University of Plymouth, Drake Circus, Plymouth PL4 8AA, United Kingdom
}

\begin{abstract}
The spatial variability in population structure of the shore crab Carcinus maenas was studied in a shallow-water fjord in the island of Fyn, Denmark. The fjord comprises an enclosed area which is geomorphologically divided into a shallow cove (mean depth $2 \mathrm{~m}$ ), known as Kertınge Nor, and a deeper narrow area, closer to the open sea, known as Kerteminde Fjord. Tidal range is small (ca $20 \mathrm{~cm}$ ). Sex-ratio favoured males at most of the sites sampled with the exception of the inland slope between the shallow Kertinge Nor and the deeper Kerteminde Fjord, which apparently was a spawning site. Crab densities were much higher in Kertemınde Fjord than in the shallower Kertinge Nor. Ventral carapace colour varied between green and orange-red, with the proportion of the green morphotype increasing with increasing distance from the open sea. Analysis of the population size structure identified 3 differentiated areas for both male and female crabs. Sites closer to the mouth of the fjord were characterized by a numerical dominance of small crabs, whereas crabs in Kertinge Nor were clearly of a much larger size. Sites in Kerteminde Fjord were characterized by a wider range of sizes. Some crabs in Kerteminde Fjord carried epibionts on the carapace, but those were absent in crabs from Kertinge Nor; moreover, a few crabs in Kertinge Nor carried Mytilus edulis byssus threads indicating that epibionts had fallen from the carapaces. Thus, population structure characteristics, such as colour morphotype proportions, size structure and occurrence of epibionts, are in accordance with the occurrence of a high degree of environmental variability in the area decreasing towards the mouth of the fjord and the open sea.
\end{abstract}

KEY WORDS: Carcinus maenas · Population structure - Crabs · Brachyura

\section{INTRODUCTION}

The shore crab Carcinus maenas (L.) is a widely distributed species inhabiting European Atlantic coasts and estuaries. It is also present on the North-American Atlantic coasts (Berrill 1982) and has recently colonised some areas in southern Africa, Australia and the Pacific coast of North America (Cohen et al. 1995). Its populations are known to show phenotypic variability which appears to be adaptively adjusted to the high variety of environmental conditions that this species can withstand (Reid et al. 1989). C. maenas is known to

\footnotetext{
•E-mail:pere@icm.csic.es
}

occur from the high intertidal, where megalopae settle and metamorphose (Zeng et al. 1997), down to a maximum depth of around $60 \mathrm{~m}$, although usually the numbers of crabs are greatly reduced below 20 m (Crothers 1968, Ingle 1980, 1983, Clark 1986). It is also common in estuaries (McVean \& Findlay 1979. McGaw \& Naylor 1992a). Adult individuals migrate up and down the shore with the tide, whereas juvenile crabs tend to remain in the high intertidal zone (Dare \& Edwards 1981, Hunter \& Naylor 1993, Warman et al. 1993). The species is therefore exposed to highly variable environmental characteristics, some of which vary cyclically and to which the species has evolved adaptive rhythmic behaviour controlled endogenously (Naylor 1985,1988 ). 
Variability in population characteristics should therefore reflect the phenotypic adaptive responses shown by individual crabs in relation to their ability to withstand environmental variability. Thus, different physiological and behavioural responses are known to take place in Carcinus maenas in relation to sex, size, and time elapsed in intermoult since the last moult (Reid et al. 1989, Kaiser et al. 1990, McGaw \& Naylor 1992b, McGaw et al. 1992, Warman et al. 1993, Aagaard et al. 1995). Time since the last moult can be recognised by gradual changes in the ventral colouration of the crab from green in the early intermoult to orange and red forms if intermoult is prolonged (Reid et al. 1989, Kaiser et al. 1990, McGaw et al. 1992). A differential response to changes in salinity, oxygen content, and mating success is known to take place among the different colour phenotypes of the species (Reid et al. 1989, Abelló et al. 1994) and is reflected in different behaviour and distributions on the shore in tidal areas (Hunter \& Naylor 1993, Warman et al. 1993). However, not much is known on the ecophysiology and behavioural ecology of Carcinus spp. from non-tidal areas, such as the almost tideless Baltic Sea

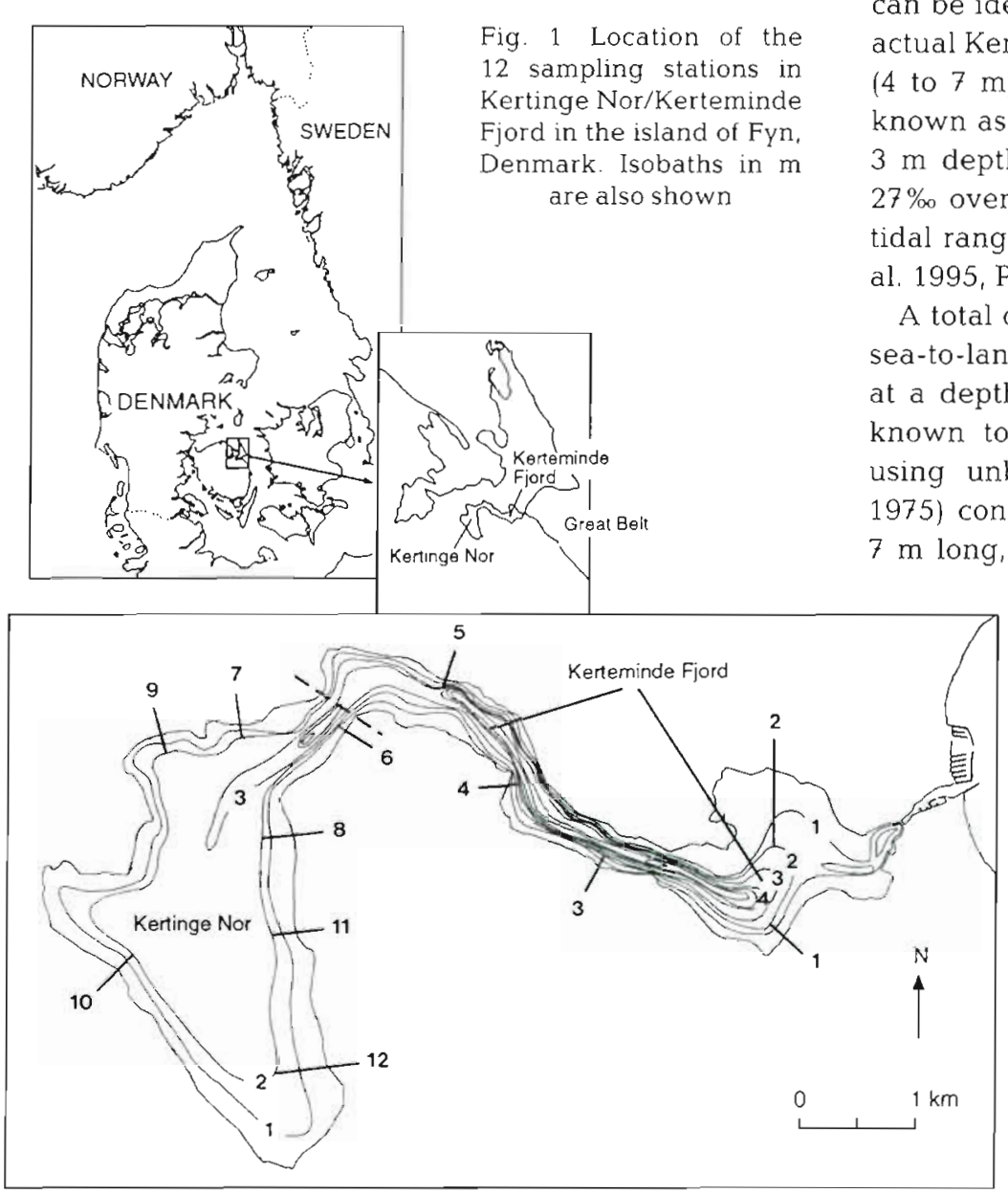

(Rasmussen 1973, Warman et al. 1991, Aagaard et al. 1995).

The study site, Kerteminde Fjord, a shallow-water, weakly tidal Danish fjord, is considered to be an unstable eutrophic ecosystem (Riisgaard et al. 1995). Carcinus maenas thrive in this habitat (Aagaard et al. 1995) and considerable variability in the degree of environmental stress experienced by the crabs in this relatively small area, particularly quick salinity and temperature changes, is known to take place (Jürgensen 1995, Petersen \& Svane 1995, Riisgaard et al. 1996). The present study therefore set out to analyse variability in population characteristics of C. maenas in such a locality, which could be related to the degree of environmental variation to which the population is subjected.

\section{MATERIALS AND METHODS}

Sampling was carried out in Kerteminde Fjord (Fig. 1), a shallow water fjord located in the northern part of Fyn, near Odense, in Denmark $\left(55^{\circ} 26^{\prime} \mathrm{N}\right.$, $\left.10^{\circ} 37^{\prime} \mathrm{E}\right)$. Two geomorphologically different subareas can be identified: the one nearest to the open sea, the actual Kerteminde Fjord, is narrow and relatively deep (4 to $7 \mathrm{~m}$ ), whereas that farthest from the open sea, known as Kertinge Nor, is a shallow cove of less than $3 \mathrm{~m}$ depth. Salinity varies typically between 14 and $27 \%$ over the year (Riisgaard et al. 1995, 1996), and range varies between 10 and $30 \mathrm{~cm}$ (Aagaard et , Petersen \& Svane 1995).

tal of 12 sampling stations were distributed in a sea-to-land gradient (Fig. 1). All stations were located at a depth of approximately $2 \mathrm{~m}$, where crabs were known to be abundant. Crab sampling took place using unbaited fixed eel-nets (fyke nets; Nédélec 1975 ) consisting of 2 funnel conical nets linked by a high vertical net which intercepted the movements of the crabs. Each net cone was $3.5 \mathrm{~m}$ long with an entrance diameter of $70 \mathrm{~cm}$, narrowing down to $30 \mathrm{~cm}$ and with 3 built-in funnels to prevent crabs from escaping the net. The nets were left overnight, the period of highest activity for the species in the study area (Aagaard et al. 1995). Sampling was performed on 4 consecutive days in April 1993. All crabs caught were counted and examined for sex, size (carapace width, CW, to the nearest $\mathrm{mm}$ ), reproductive condition (occurrence of ovigerous females), colour morphotype ('green' and 'red'; according to McGaw et al. 1992), oc- 
currence and type of epibionts, and chela loss. A total of 3915 crabs (2036 males and 1879 females) were examined.

The significance of deviations between observed and expected (1:1) sex-ratio was tested with a $G$-test (Sokal \& Rohlf 1981). Cluster analysis based on the resemblance between size frequency distributions by site was applied to male and female crabs by using Czekanowski's percentage similarity index (Goodall 1978) as the similarity index and the UPGMA (Unweighted Pair Group Method using Arithmetic Averages) as the aggregation algorithm. Czekanowski's percentage similarity index $\left\{P S=2 \cdot\left[\operatorname{sum}\left(\min \left(x_{i}, y_{i}\right)\right) /\right.\right.$ $\left.\left.\left(\operatorname{sum}\left(x_{1}+y_{i}\right)\right)\right]\right\}$ is a measure of the intersection surface in relation to the reunion surface of 2 equal area frequency distributions. LAWI software ( $\mathrm{J}$. Lleonart unpubl.) was used to perform the analysis.

\section{RESULTS}

\section{Patterns of abundance}

The overall and per sex catch per unit effort (CPUE, expressed as number of crabs caught per eel-net per night) per sampling site (Fig. 2) shows that the highest densities, of over 100 crabs, were found throughout Kerteminde Fjord to the mouth of Kertinge Nor, i.e. between Sites 2 and 7 to 8 . Densities were much lower throughout the shallow Kertinge Nor, between Sites 8,9 and 12 .

Densities of male crabs were generally much higher than those of female crabs, with the exception of Sites 4, 5 and 12. Female densities were highest at Site 5.

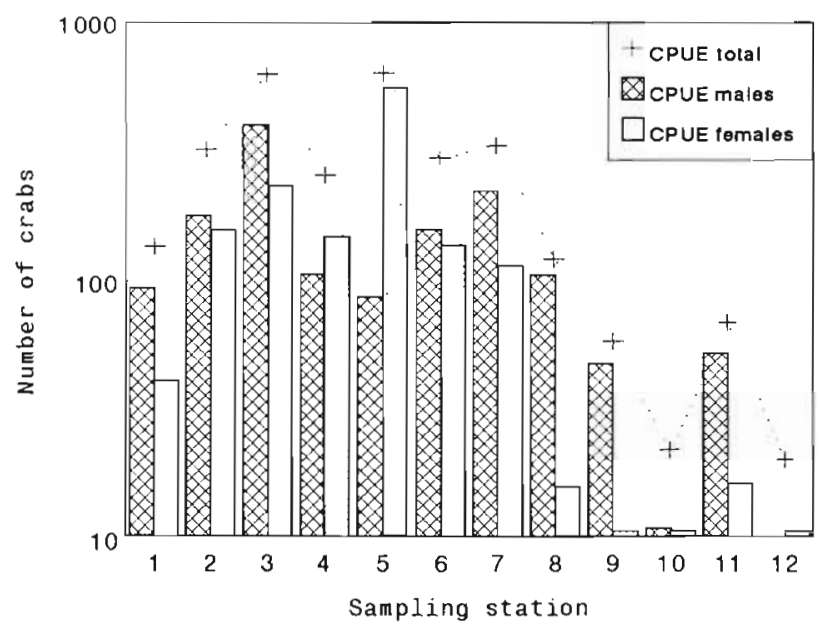

Fig. 2. Carcinus maenas. Catch per unit effort (CPUE) per sampling site, as total number and number of male and female crabs caught per eel-net per night
The highest relative proportions of male crabs were found in Kertinge Nor. Sex-ratio significantly favoured males at Sites $1,3,7,8,9$, and 11, and significantly favoured females at Sites 4 and 5 (Fig. 3).

\section{Colour morphotype variability}

The proportion of green crabs clearly increased from the sites located near the mouth of Kerteminde Fjord, which had the lowest proportion of green crabs, to those in Kertinge Nor (Table 1). Thus the male population varied between $46.3 \%$ green crabs at Site 1 and $88.6 \%$ at Site 11 . A similar pattern was also exhibited by female crabs, with the proportion of the green morphotype ranging from $20.7 \%$ at Site 1 (that nearest to the open sea) to $68.8 \%$ at Sites 8 and 10 , in Kertinge Nor.

\section{Population size structure}

Figs. 4 \& 5 show the size frequency distributions obtained for males and females, respectively, differentiating between green and red colour morphotypes, in $3 \mathrm{~mm} \mathrm{CW}$ size classes. There was a clear tendency for size to increase from Kerteminde Fjord to Kertinge Nor in both male and female crabs. Thus, mean male size increased from $40.5 \mathrm{~mm}$ CW at Site 1 near the mouth of Kerteminde Fjord to $61.3 \mathrm{~mm} \mathrm{CW}$ at Site 12 at the farthest end of Kertinge Nor (Table 1), whereas in females, mean size increased from $37.0 \mathrm{~mm} \mathrm{CW}$ at Site 1 to $53.1 \mathrm{~mm} \mathrm{CW}$ at Site 10 or $52.5 \mathrm{~mm} \mathrm{CW}$ at Site 1.2 in Kertinge Nor. Other descriptors of the distributions, as

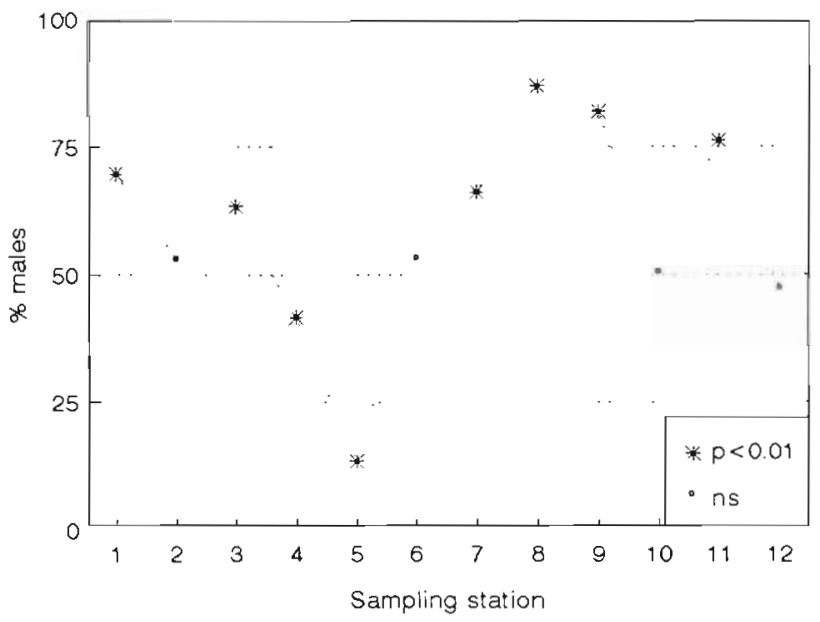

Fig. 3. Carcinus maenas. Sex-ratio, as percentage male crabs, at each sampling station, with indication (stars) of those samples which showed a significantly different proportion from a theoretical 1:1 sex-ratio 
Table 1. Carcinus maenas. Characteristics of the population sampled in Kerteminde Fjord per sampling site in April 1993. CPUE: catch per unit effort, in number of individuals caught by eel-net per night; size: carapace width, in mm; SD: standard deviation; byssus: Mytilus edulis byssus threads on the carapace

\begin{tabular}{|c|c|c|c|c|c|c|c|c|c|c|c|c|}
\hline Site & 1 & 2 & 3 & 4 & 5 & 6 & 7 & 8 & 9 & 10 & 11 & 12 \\
\hline Samples taken & 2 & 2 & 1 & 2 & 1 & 1 & 1 & 1 & 3 & 3 & 2 & 3 \\
\hline Total number & 270 & 672 & 632 & 507 & 644 & 294 & 336 & 121 & 175 & 65 & 138 & 61 \\
\hline Number of males & 188 & 357 & 400 & 211 & 86 & 157 & 222 & 105 & 143 & 33 & 105 & 29 \\
\hline Number of females & 82 & 315 & 232 & 296 & 558 & 137 & 114 & 16 & 32 & 32 & 33 & 32 \\
\hline$\%$ males & 69.6 & 53.1 & 63.3 & 41.6 & 13.4 & 53.4 & 66.1 & 86.8 & 81.7 & 50.8 & 76.1 & 47.5 \\
\hline \multicolumn{13}{|l|}{ Males } \\
\hline Mean size & 40.5 & 42.0 & 46.0 & 49.4 & 52.9 & 49.6 & 54.5 & 55.5 & 55.6 & 57.8 & 58.8 & 61.3 \\
\hline SD & 7.2 & 7.8 & 9.4 & 10.4 & 9.7 & 9.6 & 8.2 & 7.8 & 7.7 & 6.7 & 7.6 & 8.2 \\
\hline Minimum size & 24 & 27 & 29 & 30 & 34 & 29 & 34 & 35 & 33 & 39 & 39 & 38 \\
\hline Maximum size & 59 & 73 & 79 & 78 & 77 & 76 & 76 & 76 & 81 & 72 & 74 & 79 \\
\hline Median & 40.0 & 41.0 & 45.0 & 49.0 & 53.0 & 50.0 & 55.0 & 57.0 & 56.0 & 59.0 & 59.0 & 60.0 \\
\hline Mode & 45 & 36 & 43 & 61 & 56 & 55 & 50 & 59 & 54 & 61 & 59 & 60 \\
\hline \multicolumn{13}{|l|}{ Females } \\
\hline Mean size & 37.0 & 38.9 & 37.8 & 41.5 & 42.4 & 44.6 & 48.1 & 48.9 & 50.6 & 53.1 & 51.7 & 52.5 \\
\hline SD & 4.6 & 5.5 & 6.9 & 6.2 & 5.7 & 6.7 & 6.0 & 6.8 & 7.8 & 6.5 & 6.5 & 5.8 \\
\hline Minimum size & 29 & 25 & 27 & 28 & 32 & 30 & 37 & 36 & 36 & 39 & 37 & 40 \\
\hline Maximum size & 50 & 60 & 65 & 60 & 64 & 65 & 65 & 60 & 66 & 66 & 67 & 64 \\
\hline Median & 37.0 & 38.0 & 36.0 & 41.0 & 42.0 & 44.0 & 48.0 & 48.5 & 51.0 & 52.5 & 52.0 & 53.5 \\
\hline Mode & 37 & 38 & 34 & 42 & 40 & 44 & 44 & 57 & 51 & 58 & 52 & 57 \\
\hline$\%$ green males & 46.3 & 57.1 & 79.8 & 51.7 & 67.4 & 71.3 & 77.0 & 81.9 & 82.5 & 78.8 & 88.6 & 79.3 \\
\hline$\%$ green females & 20.7 & 41.9 & 55.2 & 39.2 & 57.7 & 43.1 & 58.8 & 68.8 & 62.5 & 68.8 & 66.7 & 56.3 \\
\hline$\%$ ovigerous females & 0.0 & 2.5 & 2.6 & 1.0 & 1.4 & 2.2 & 0.0 & 12.5 & 6.3 & 9.4 & 9.1 & 12.5 \\
\hline$\%$ with epibionts & 1.5 & 8.9 & 8.4 & 1.6 & 0.9 & 0.0 & 0.0 & 0.0 & 0.0 & 0.0 & 0.0 & 0.0 \\
\hline$\%$ with barnacles & 1.5 & 7.0 & 3.3 & 0.2 & 0.5 & 0.0 & 0.0 & 0.0 & 0.0 & 0.0 & 0.0 & 0.0 \\
\hline$\%$ with algae & 0.0 & 0.3 & 0.3 & 0.4 & 0.0 & 0.0 & 0.0 & 0.0 & 0.0 & 0.0 & 0.0 & 0.0 \\
\hline$\%$ with hydrozoans & 0.0 & 1.2 & 0.5 & 0.0 & 0.0 & 0.0 & 0.0 & 0.0 & 0.0 & 0.0 & 0.0 & 0.0 \\
\hline$\%$ with mussels & 0.0 & 0.0 & 0.0 & 0.0 & 0.2 & 0.0 & 0.3 & 1.7 & 0.0 & 0.0 & 0.7 & 0.0 \\
\hline$\%$ with byssus & 0.0 & 0.6 & 1.3 & 0.8 & 0.3 & 0.0 & 0.6 & 0.8 & 0.6 & 0.0 & 2.9 & 0.0 \\
\hline$\%$ males with chela loss & 2.7 & 5.6 & 3.8 & 3.8 & 4.7 & 6.4 & 7.7 & 9.5 & 7.7 & 6.1 & 9.5 & 17.2 \\
\hline$\%$ females with chela loss & 8.5 & 6.0 & 3.9 & 5.1 & 6.6 & 1.5 & 12.3 & 12.5 & 12.5 & 3.1 & 6.1 & 3.1 \\
\hline
\end{tabular}

median and modal values, also showed this tendency to increase with increasing distance from the mouth of the fjord (Table 1). Large crabs, as shown by the maximum sizes found at each site, occurred at most stations from Site 3 onwards, but the minimum size clearly increased following the same tendency as mean size (Table 1).

To compare and establish similarities among the samples based on the resemblance in shape of size frequency distributions, samples were compared by means of the percentage similarity index to create a similarity matrix among all of the samples. Samples were accordingly grouped to build a graphic dendrogram (Fig. 6). This descriptive technique allowed the identification of discrete areas in the fjord which showed a high degree of similarity in the size structure of the crab population sampled. Cluster analysis showed a high degree of classification, with a high cophenetic correlation 10.678 for males, 0.829 for females) and a low degree of enchainment $(0.218$ for males, 0.127 for females). Thus, 3 main groups of samples were identified for both male and female crabs according to their size frequency distribution resemblance. The first dichotomy of the 2 dendograms clearly separated the samples from Kertinge Nor (Sites 7 to 12) from those in Kerteminde Fjord (Sites 1 to 6). Within the samples from Kerteminde Fjord, those nearest to the mouth of the fjord formed a distinct group (Sites 1 and 2 in males, Sites 1 to 3 in females).

\section{Epibionts}

A few crabs were found carrying marine macroepibionts, especially barnacles, algae, mussels and hydrozoans, on their carapaces (Table 1). However, only the crabs in Kerteminde Fjord (at Sites 1 to 5) were found to carry epibionts on their carapaces, whereas none of those collected in Kertinge Nor were. Furthermore, a few crabs were found with Mytilus edulis byssus threads attached to their carapaces, indicating that those crabs had previously carried mussels, but that they had fallen off. 
Males
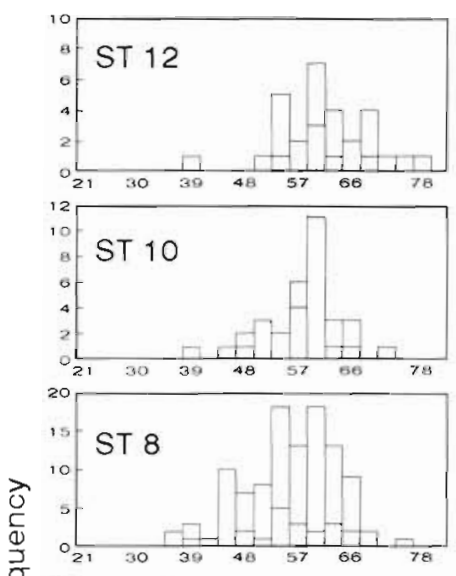

崩
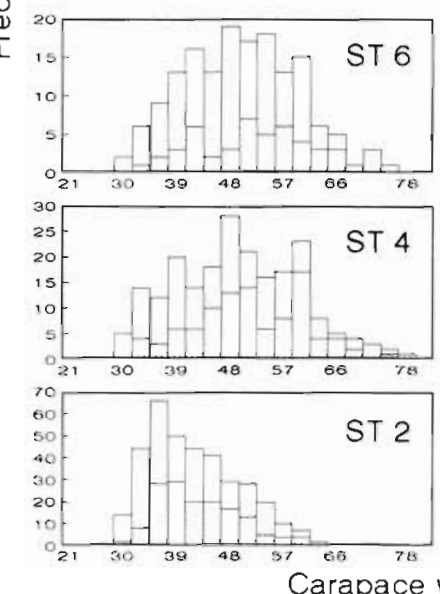

Carapace width $(\mathrm{mm})$

Fig. 4. Carcinus maenas. Size frequency distribution of males at each sampling station in $3 \mathrm{~mm}$ carapace width size classes, showing red (shaded) and green (clear) colour morphotypes
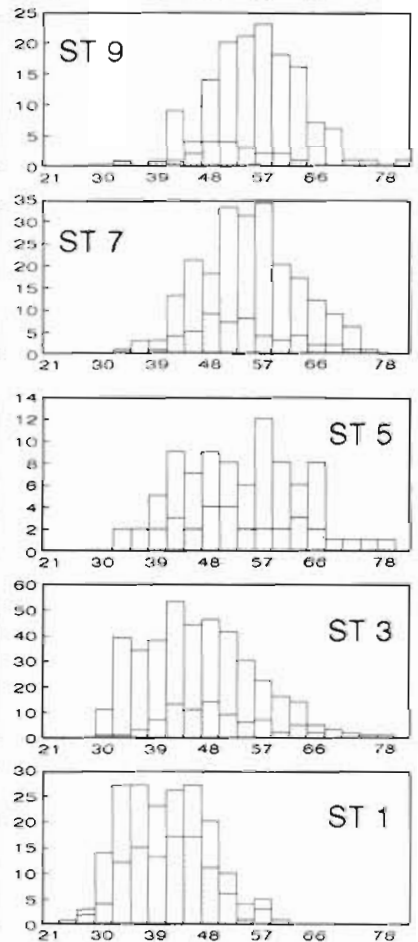

ST 1
Females
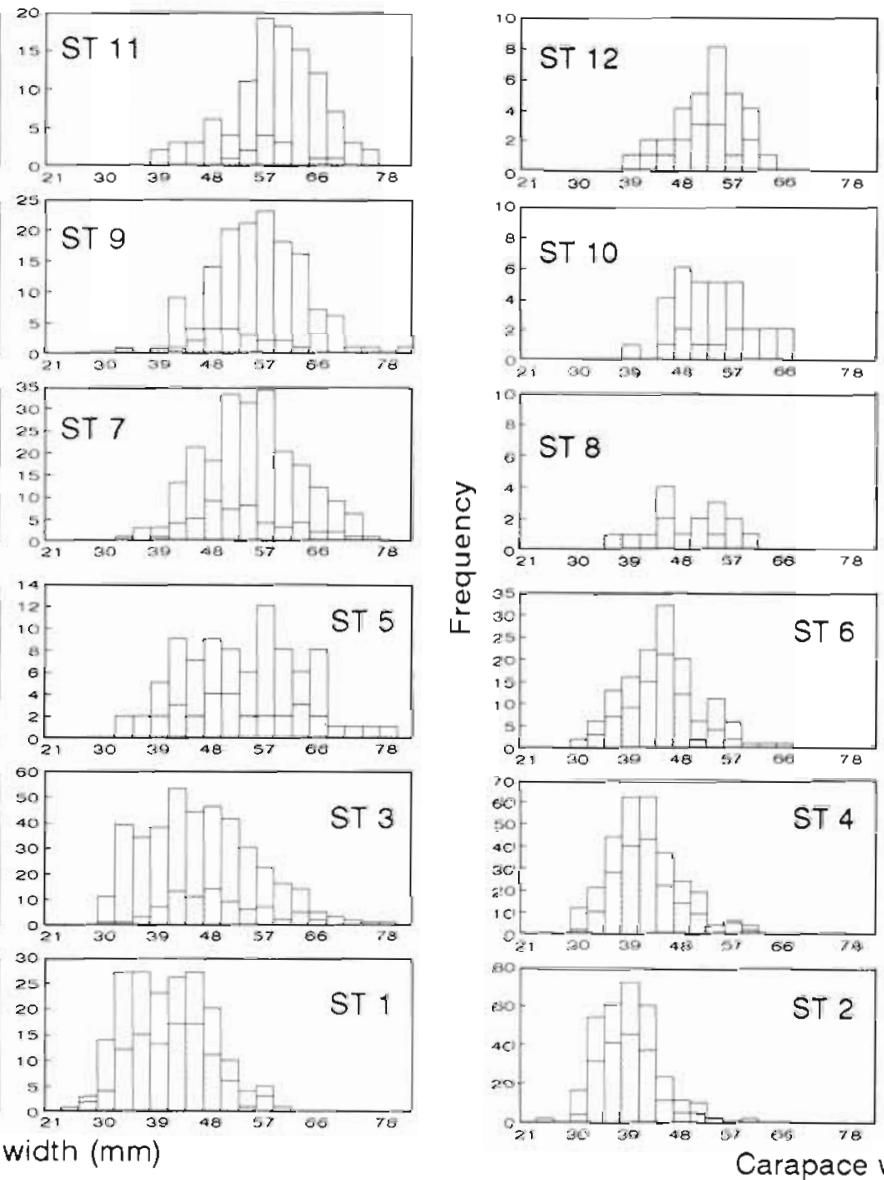

ST 2
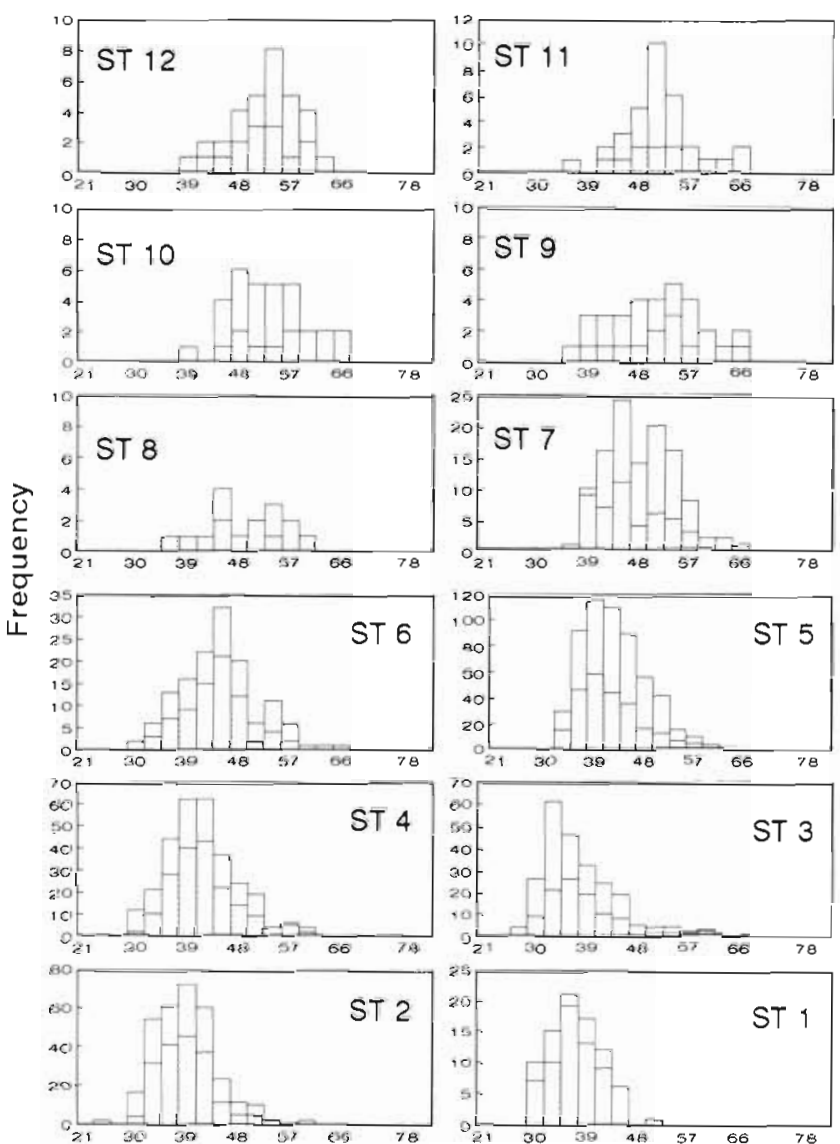

Fig. 5. Carcinus maenas. Size frequency distribution of females at each sampling station in $3 \mathrm{~mm}$ carapace width size classes, showing red (shaded) and green (clear) colour morphotypes

\section{Chela loss}

The proportion of male crabs with chela loss ranged between $2.7 \%$ at Site 1 and $17.2 \%$ at Site 12. The proportion was clearly higher in Kertinge Nor than in Kerteminde Fjord (Table 1). In females, however, this tendency was not as marked, probably due to the small number of female crabs captured at Sites 10 to 12 .

\section{DISCUSSION}

Kerteminde Fjord is a eutrophic ecosystem with high physical and biological variability in which the biological structure is controlled by the interactions between primary producers (phytoplankton, macroalgae and seagrass Zostera marina), suspension feeders (especially the ascidian Ciona intestinalis) (Petersen \& Riis-
Males

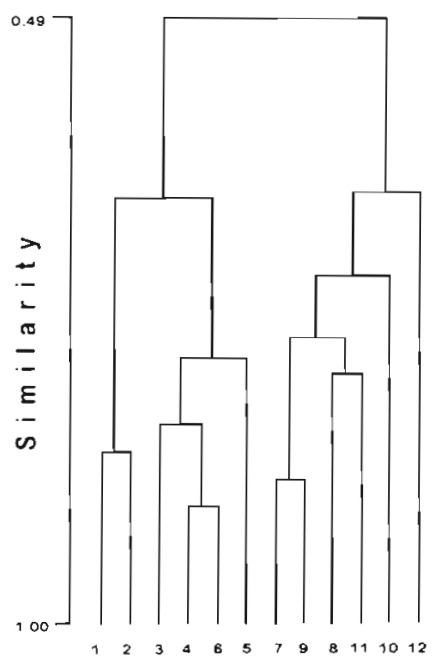

Fig. 6. Carcinus maenas. Dendrogram of similarity between sampling stations based on size frequency distribution resemblance in males and females

\section{Females}

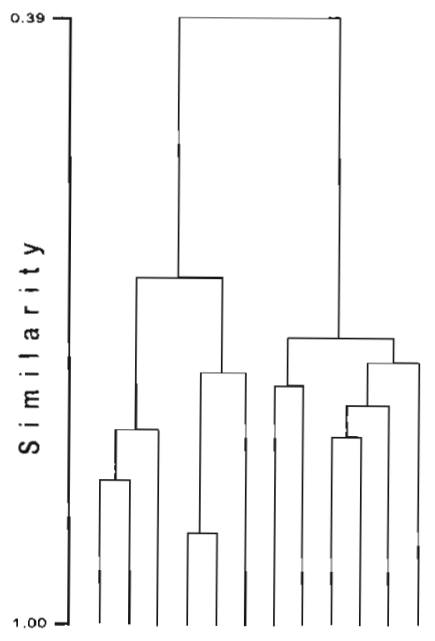


gaard 1992), zooplankton predators (the jellyfish Aurelia aurita) (Olesen et al. 1994) and mobilization of nutrients from the sediment (Riisgaard et al. 1995). The high densities of Carcinus maenas reported in the present paper must also play an important role in predation on benthos, sediment turnover, and nutrient release, especially during the warm season when foraging activity and predation rates are highest (Aagaard et al. 1995).

Environmental variability is known to be high in the study area, particularly concerning salinity and temperature variations (Jürgensen 1995, Petersen \& Svane 1995, Riisgaard et al. 1996). The density-driven hydrographic circulation in the study area is forced by the small tide and is known to be highly variable, depending on the water input from the open sea which can be of either low salinity Baltic Sea waters or higher salinity North Sea waters (Riisgaard et al. 1996). Densitydriven circulation creates salinity gradients within the fjord which can be reversed depending on the open sea water characteristics entering the fjord. Freshwater input to the fjord is considered to be negligible (Jürgensen 1995, Riisgaard et al. 1996). Furthermore, most of the seabed in Kerteminde Fjord is made of soft (sandy/muddy) sediment with scattered stands of bladderwrack Fucus vesiculosus and eelgrass Zostera marina, whereas Kertinge Nor is dominated by $Z$. marina, the filamentous alga Chaetomorpha linum and the ascidian Ciona intestinalis which tend to form a dense cover over the area (Petersen \& Svane 1995, Riisgaard et al. 1995). In fact, Riisgaard et al. (1995) reported a high biomass of filamentous macroalgae in 1991 and halfway through 1992 when the algae formed thick mats of up to $40 \mathrm{~cm}$ during the growth season. This caused oxygen depletion on the fjord bottom (Krause-Jensen et al. 1996). The filamentous macroalgae, however, disappeared in the summer of 1992 and they have not come back since (H. U. Riisgaard pers. comm.). Carcinus maenas living in Kertinge Nor are therefore exposed to quick and wide salinity variations, temperature variations assumed to be greater as it is shallower there, oxygen depletion, dense macrophytobenthos, etc., which make this environment more stressful for marine life than Kerteminde Fjord.

Carcinus maenas of the green morphotype are known to withstand a greater environmental stress than red crabs (Reid et al. 1989, McGaw \& Naylor 1992b. McGaw et al. 1992), in particular in relation to oxygen decrease tolerance (Reid \& Aldrich 1989), and they are more resistant to toxic pollutants than red crabs (Aagaard, Warman \& Depledge unpubl.). Although there is no clear separation between green and orange-red morphotypes (see Reid et al. 1989), the increasing proportion of green crabs in the fjord is con- sistent with the occurrence of increasing environmental variability in conditions. Thus, the pattern observed in the present field study is consistent with the ecophysiological differences reported in the literature between the 2 colour morphotypes

Differences in the crab population size structure observed within the fjord allowed the detection of 3 well-differentiated, and rather internally homogeneous, areas in the fjord. Although large crabs can be found throughout the fjord, it is the smaller crabs which appear to be most affected by the environmental conditions in Kertinge Nor, since they seem to avoid the area.

The strongly biased sex-ratio towards the females at the inland slope between the shallow Kertinge Nor and the deeper Kerteminde Fjord (Sites 4 to 5) and the fact that most of them were found to be spawning or ready to spawn, indicates that the area was apparently a spawning site.

The absence of epibionts on the carapaces of crabs from Kertinge Nor, and in particular the occurrence of mussel byssus threads, further support the view of the occurrence of strong environmental variability in Kertinge Nor. This suggests that marine epibiont organisms could not tolerate the environmental conditions found in the shallow area, as indicated by mussels, which apparently could no longer adhere to crab carapaces. In fact, only small individuals of Mytilus edulis have been reported in Kertinge Nor, as epibionts on Zostera marina (Petersen \& Svane 1995).

Chela loss was also higher in Kertinge Nor than in Kerteminde Fjord. The most important factors affecting the degree of chela loss in crabs are predation and intraspecific conflicts (McVean \& Findley 1979, Smith $\&$ Hines 1991, Abelló et al. 1994). Since there is no evidence to suggest that predation on crabs may be higher in Kertinge Nor, the higher degree of chela loss in Kertinge Nor is probably due to a size effect, since chela loss is higher in larger-sized crabs, especially in males (Abelló et al. 1994), which have a larger foraging range than juveniles.

In conclusion, the present study revealed the occurrence of strong internal variability in the population characteristics of the crabs inhabiting a shallow-water fjord which is consistent with the occurrence of a gradient of environmental variability along the studied area.

Acknowledgements. All the present work was performed at the Biologisk Institut, Odense Universitet, Denmark, where A.A., C.G.W. and M.H.D. worked while sampling took place. We are most grateful to the Biologisk Institut staff and students at the time and especially to Dr H. U. Riisgaard for his constructive comments on the manuscript. Special thanks for field assistance and comments provided are due to R. Andersen, S and M. Helholm, and B. Styrishave. Drs J. Lleonart (ICM, Barcelona) and D. G. Reid (SOAEFD, Aberdeen) kindly 
provided statistical advice and helpful comments. P.A. thanks the European Science Foundation for travel funding. The bulk of this work was funded by a Danish Science Research Council grant held by M.H.D.

\section{LITERATURE CITED}

Aagaard A, Warman CG, Depledge MH (1995) Tidal and seasonal changes in the temporal and spatial distribution of foraging Carcinus maenas in the weakly tidal littoral zone of Kerteminde Fjord, Denmark. Mar Ecol Prog Ser 122: $165-172$

Abelló P, Warman CG, Reid DG. Naylor E (1994) Chela loss in the shore crab Carcinus maenas (Crustacea: Brachyura) and its effect on mating success. Mar Biol 121:247-252

Berrill M (1982) The life cycle of the green crab Carcinus maenas at the northern end of its range. J Crustacean Biol $2: 31-39$

Clark PF (1986) North east Atlantic crabs; an atlas of distributıon. Marine Conservation Society, Ross-on-Wye

Cohen AN, Carlton JT, Fountain MC (1995) Introduction, dispersal and potential impacts of the green crab Carcinus maenas in San Francisco Bay, California. Mar Biol 122: $225-237$

Crothers JH 11968\} The biology of the shore crab Carcinus maenas (L.). 2. The life of the adult crab. Field Stud 2: $579-614$

Dare PJ, Edwards DB (1981) Underwater television observations on the intertidal movements of shore crabs, Carcinus maenas, across a mudflat. J Mar Biol Ass UK 61:107-116

Goodall DW (1978) Sample similarity and species correlation. In: Whittaker $\mathrm{H}$ (ed) Ordination of plant communities. Dr W Junk Publishers, The Hague, p 99-149

Hunter E, Naylor E (1993) Intertidal migration by the shore crab Carcinus maenas. Mar Ecol Prog Ser 101:131-138

Ingle RW (1980) British crabs. Oxford University Press, Oxford, and British Museum (Natural History), London

Ingle RW (1983) Shallow-water crabs. Synopses of the Brıtish fauna (NS). Cambridge University Press and The Estuarine and Brackish-water Sciences Association, Cambridge

Jürgensen $C$ (1995) Modelling of nutrient release from the sediment in a tidal inlet, Kertinge Nor, Funen, Denmark. Ophelia 42:163-178

Kaiser MJ, Hughes RN, Reid DG (1990) Chelal morphometry, prey-size selection and aggressive competition in green and red forms of Carcinus maenas (L.).J Exp Mar Biol Ecol 140:121-134

Krause-Jensen D, McGlathery K, Rysgaard S, Christensen PB (1996) Production within dense mats of the filamentous macroalga Chaetomorpha linum in relation to light and nutrient availability. Mar Ecol Prog Ser 134:207-216

McGaw IJ, Kaiser MJ, Naylor E, Hughes RN (1992) Intraspecific morphological variation related to the moult-cycle in colour forms of the shore crab Carcinus maenas. J Zool (Lond) 228:351-359

This article was submitted to the editor
McGaw IJ, Naylor E (1992a) Distribution and rhythmic locomotor patterns of estuarine and open-shore populations of Carcinus maenas. J Mar Biol Ass UK 72:599-609

McGaw IJ, Naylor E (1992b) Salinity preference of the shore crab Carcinus maenas in relation to coloration during intermoult and to prior acclimation. J Exp Mar Biol Ecol $155: 145-159$

McVean A, Findlay I (1979) The incidence of autotomy in an estuarine population of the crab Carcinus maenas. J Mar B1ol Ass UK 59:341-354

Naylor E (1985) Tidally rhythmic behaviour of marine animals. Symp Soc Exp Biol 39:63-93

Naylor E (1988) Rhythmic behaviour of decapod crustaceans. Symp Zool Soc Lond 59:177-199

Nédélec C (1975) FAO catalogue of small-scale fishing gear Fishing News (Books) Ltd, West Byfleet

Olesen NJ, Frandsen K, Riisgaard HU (1994) Population dynamics, growth and energetics of jellyfish Aurelia aurita in a shallow fjord. Mar Ecol Prog Ser 105:9-18

Petersen JK, Riisgaard HU (1992) Filtration capacity of the ascidian Ciona intestinalis and its grazing impact in a shallow fjord. Mar Ecol Prog Ser 88:9-17

Petersen JK, Svane I (1995) Larval dispersal in the ascidian Ciona intestinalis (L.). Evidence for a closed population. J Exp Mar Biol Ecol 186:89-102

Rasmussen E (1973) Systematics and ecology of the Isefjord marine fauna (Denmark). Ophelia 11:1-495

Reid DG. Abelló P, McGaw IJ, Naylor E (1989) Phenotypic variation in sympatric crab populations. In: Aldrich JC (ed) Phenotypic responses and individuality in aquatic ectotherms. Japaga, Ashford, p 89-96

Reid DG, Aldrich JC (1989) Variations in response to environmental hypoxia of different colour forms of the shore crab. Carcunus maenas. Comp Biochem Physiol (A) 92:535-539

Riisgaard HU, Bondo Chrıstensen P, Olesen NJ, Petersen JK, Moller MM, Andersen P (1995) Biological structure in a shallow cove (Kertinge Nor, Denmark) - control by benthic nutrient fluxes and suspension-feeding ascidians and jellyfish. Ophelia 41:329-344

Riisgaard HU, Jürgensen C, Clausen T (1996) Filter-feeding ascidians (Ciona intestinalis) in a shallow cove: implications of hydrodynamics for grazing impact. J Sea Res 35:293-300

Smith LD, Hines AH (1991) Autotomy in bolue crab (Callinectes sapidus Rathbun) populations: geographic, temporal, and ontogenetic variation. Biol Bull Mar Biol Lab, Woods Hole 180:416-431

Sokal RR, Rohlf F.J (1981) Biometry. WH Freeman \& Co, New York

Warman CG, Abello P, Naylor E (1991) Behavioural responses of Carcinus mediterraneus Czerniavsky, 1884 to changes in salinity. Sci Mar 55:637-643

Warman CG, Reid DG, Naylor E (1993) Variation in the tidal migratory behaviour and rhythmic light-responsiveness in the shore crab. Carcinus maenas. J Mar Biol Ass UK 73:355-364

Zeng C, Naylor E, A.belló P (1997) Endogenous control of timing of metamorphosis in megalopae of the shore crab Carcinus maenas. Mar Biol (in press)

Manuscript first received: August 26, 1996

Revised version accepted: January 13, 1997 